\title{
Synchronous primary colonic and early gallbladder carcinomas: report of a rare case
}

\author{
Zainab I. Alruwaii ${ }^{1}$, Mohamed A. Shawarby ${ }^{2}$ \\ 1. Histopathology Department, King Fahd Hospital of the University, Al-Khobar, Saudi Arabia. 2. Pathology Department, \\ College of Medicine, University of Dammam, Dammam, Saudi Arabia.
}

Correspondence: Mohamed A. Shawarby. Address: Pathology Department, College of Medicine, University of Dammam, Dammam 31441, Saudi Arabia. E-mail: melshawarby46@hotmail.com

Received: August 13, 2014

DOI : $10.5430 /$ crcp.v2n1p48
Accepted: October 7, 2014

URL: http://dx.doi.org/10.5430/crcp.v2n1p48

\section{Abstract}

The incidence of multiple primary malignant tumors in the same individual is increasing worldwide. We report a case of a 30 years old female with an adenocarcinoma of the colon in whom a high grade dysplasia/carcinoma in situ of the gallbladder was incidentally discovered in the cholecystectomy specimen resected with the colon for multiple gall stones. Synchronous adenocarcinomas of the colon and the gallbladder are extremely rare with only seven cases reported so far. The link between the colonic and the gall bladder carcinoma may reside in the presence of gall stones rather than a hereditary predisposition to cancer development as may be suggested by a negative family history for colorectal and gallbladder cancers. Because the colon is the organ that is most frequently involved in the setting of multiple primary malignant tumors, thorough preoperative screening and follow up for other cancers, including gallbladder cancer, is recommended for patients presenting with colorectal carcinoma.

\section{Key words}

Synchronous, Colorectal, Adenocarcinoma, In situ carcinoma, Dysplasia, Gallbladder, Multiple primary malignant tumors

\section{I ntroduction}

The phenomenon of multiple primary malignant tumors (MPMT) in the same individual was first described by Warren and Gates in $1932^{[1]}$. Cancers diagnosed at the same time or within a period of six months after the diagnosis of the initial cancer are described as synchronous while those diagnosed after six months are called metasynchronous ${ }^{[2]}$. Autopsy studies on MPMT cases showed the colon to be the organ most frequently involved ${ }^{[3,4]}$, especially among the aged ${ }^{[3]}$. Herein, we report a case of a 30 years old female with an adenocarcinoma of the colon, in whom a high grade dysplasia/ carcinoma in situ of the gallbladder was incidentally discovered in the cholecystectomy specimen resected with the colectomy for multiple gall stones. Synchronous adenocarcinomas of the colon and the gallbladder are extremely rare with only seven cases reported so far ${ }^{[5-11]}$.

\section{Case presentation}

A 30 years old non-smoker, non-alcoholic female presented with central abdominal pain of six months duration, complicated by bloody diarrhea one week before admission. The pain was associated with anorexia and weight loss and 
negative history of vomiting, fever or night sweats. The patient had unremarkable medical, surgical and allergic past history. There was no family history of colorectal or gallbladder cancers. CBC showed: RBCs $2.76 \mathrm{mil} / \mu \mathrm{l}$, Hgb $5.9 \mathrm{~g} / \mathrm{dl}$, Hct 20.3\%, WBC $17.5 \mathrm{k} / \mu \mathrm{l}$ and Platelets $980 \mathrm{k} / \mu \mathrm{l}$. Colonoscopy showed an ulcerating annular mass, $26 \mathrm{~cm}$ from the anal verge that was diagnosed by biopsy as invasive moderately differentiated adenocarcinoma.

\subsection{Contrast-enhanced CT}

Contrast-enhanced CT of the abdomen and pelvis with oral contrast performed after colonoscopy showed marked sigmoid wall thickening with stricture and infiltration of adjacent fat and the posterior bladder wall consistent with the diagnosis of cancer (see Figure 1). There were as well multiple laminated large gallbladder stones (see Figure 1A). The patient underwent exploratory laparotomy with sigmoid resection and end to end anastomosis, with partial cystectomy, salpingooorphectomy and cholecystectomy. In a study performed by Juhasz et al. ${ }^{[12]}$ on 305 patients it was concluded that unless there are clear contraindications, patients with asymptomatic gall stones who have colorectal surgery should have concomitant cholecystectomy. Earlier experience has also suggested that selected patients who have had adequate bowel preparation have minimal risks associated with additional intra-abdominal surgery performed at the time of colectomy ${ }^{[13]}$.

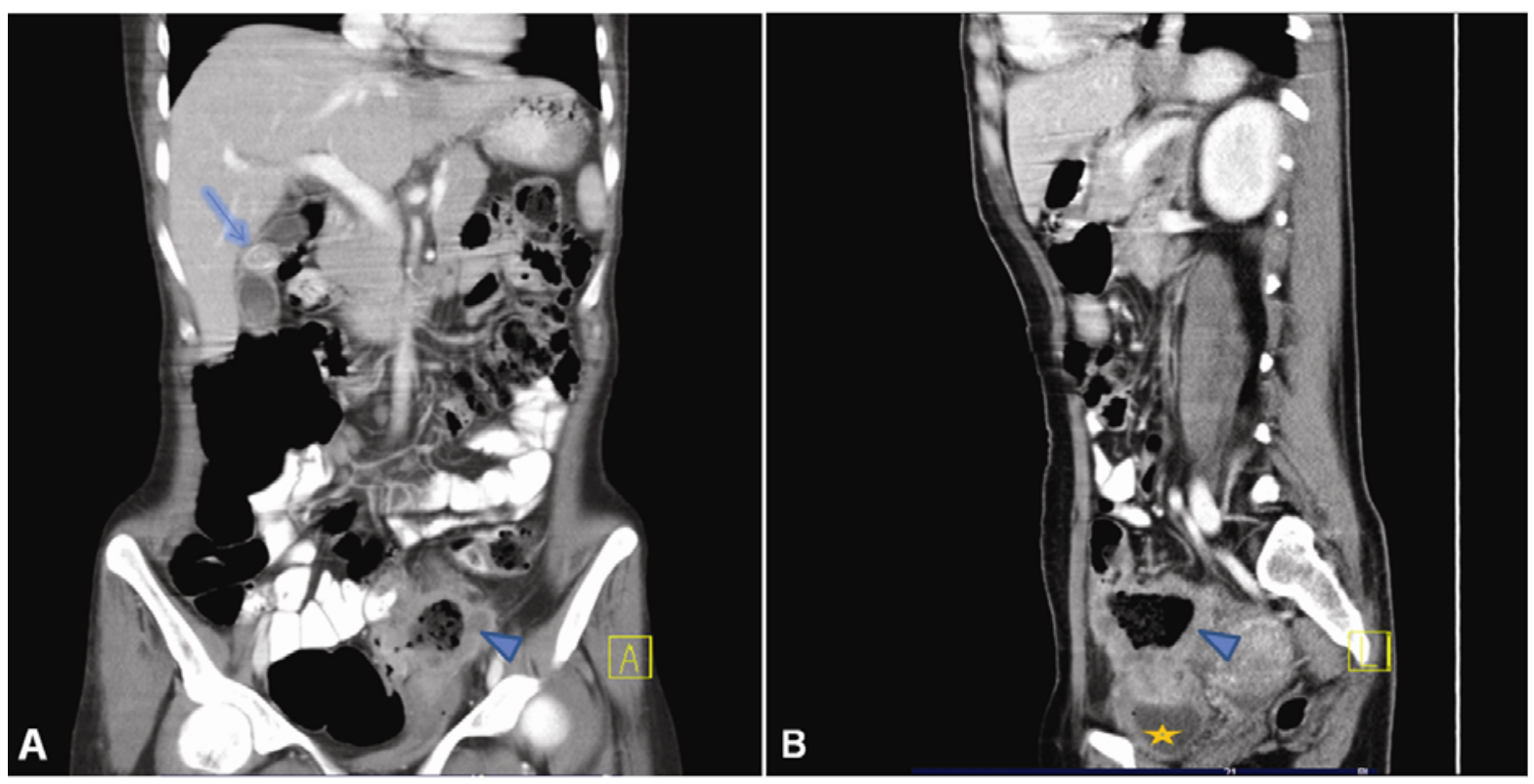

Figure 1. Coronal and sagittal CT reformats of the abdomen and pelvis. (A) Gallbladder with large calcified stone (arrow) and marked sigmoid wall thickening with adjacent mesenteric fat infiltration (arrow head); (B) Sigmoid wall thickening infiltrating urinary bladder wall (star).

\subsection{Pathologic findings}

The surgical specimen included $14 \mathrm{~cm}$ of sigmoid colon and attached part of urinary bladder and jejunal loop with a $6 \mathrm{~cm}$ $\times 5 \mathrm{~cm} \times 3.5 \mathrm{~cm}$ infiltrating hard tumor invading the urinary bladder and forming a fistula between jejunum and colon (see Figure 2A). The gallbladder specimen was received opened with no grossly identifiable masses or stones (see Figure 2B). Microscopic examination revealed a moderately differentiated adenocarcinoma of the sigmoid colon (see Figure 3) invading the urinary bladder and the jejunum (TNM stage pT4b N1 M0, group stage IIIC) along with acute and chronic cholecystitis with high grade dysplasia/carcinoma in situ extending into Rokitansky-Aschoff sinuses (TNM stage pTis N0 M0, group stage 0, see Figure 4). Immunohistochemically, the colonic cancer was CK20 and CDX2+ve, and CK7-ve, while the gallbladder cancer was CK20 and CK7+ve, and CDX2-ve (see Figure 5 and 6).

Postoperatively, the patient was stable and she was referred to another center for chemotherapy. 
Figure 2. (A) Infiltrating tumor in sigmoid colon; (B) Opened gallbladder with no grossly identifiable tumor

Figure 3. Moderately differentiated adenocarcinoma infiltrating sigmoid submucosa. $\mathrm{H} \& \mathrm{E} \times 200$

Figure 4. (A) High grade dysplasia/carcinoma in situ involving gallbladder lining. $\mathrm{H} \& \mathrm{E} \times 100$; (B) High grade dysplasia/carcinoma in situ extending into RokitanskyAschoff sinuses in gallbladder wall. $\mathrm{H} \& \mathrm{E} \times 100$
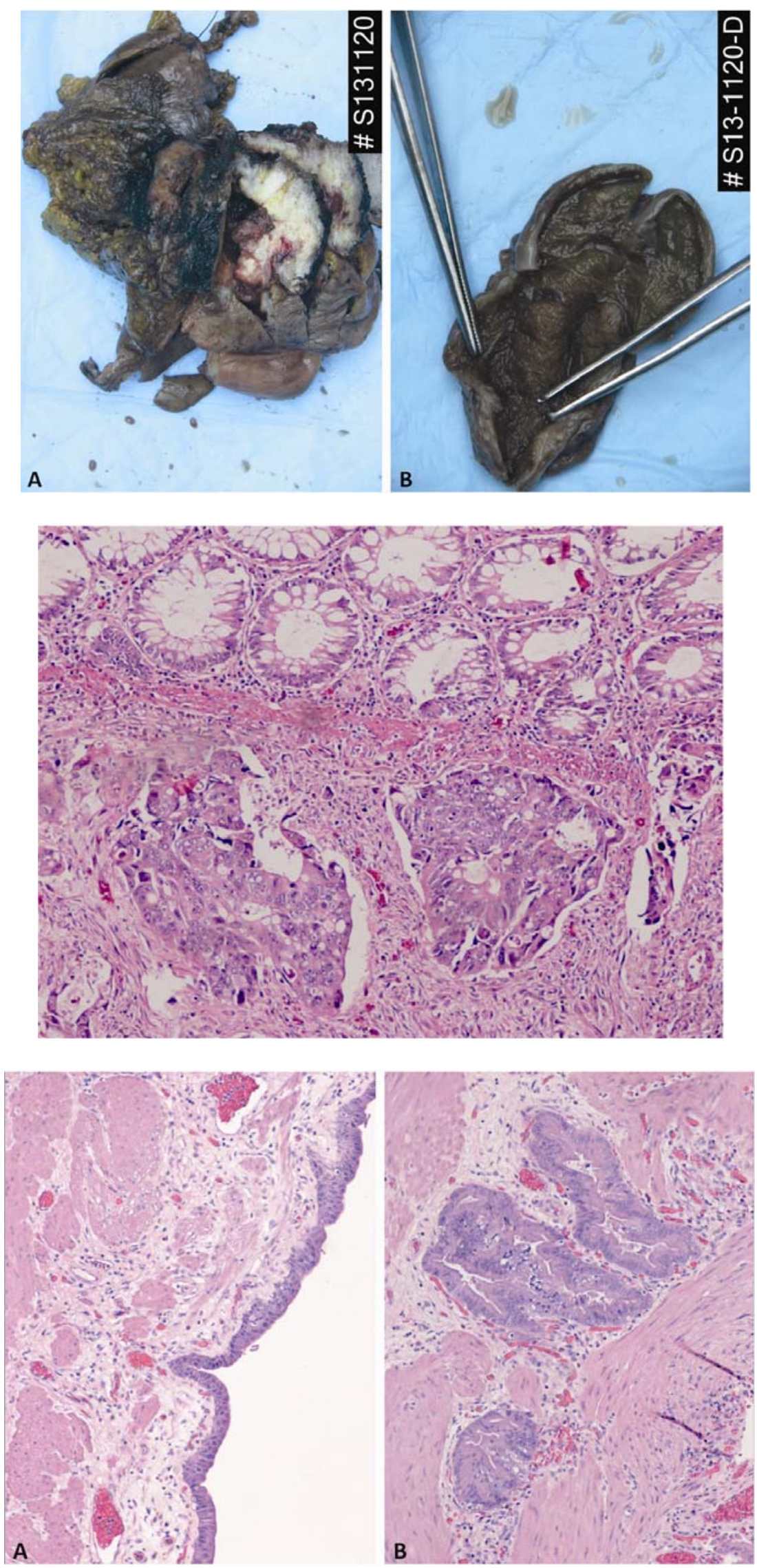
Figure 5. (A) Colonic adenocarcinoma showing negative immunoreactivity for CK7. IHC ×100; (B) Gall bladder high grade dysplasia/carcinoma in situ showing positive immunoreactivity for CK7. IHC $\times 100$
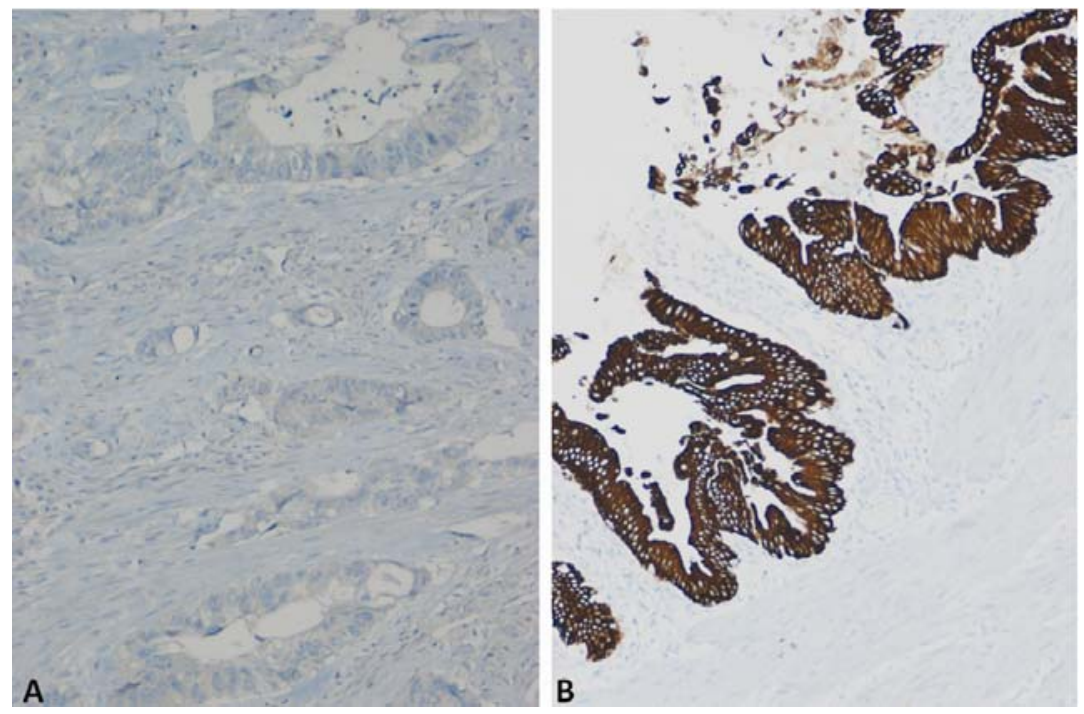

Figure 6. (A) Colonic adenocarcinoma showing positive immunoreactivity for CDX2. IHC $\times 100$; (B) Gall bladder high grade dysplasia/carcinoma in situ showing negative immunoreactivity for CDX2. IHC $\times 100$
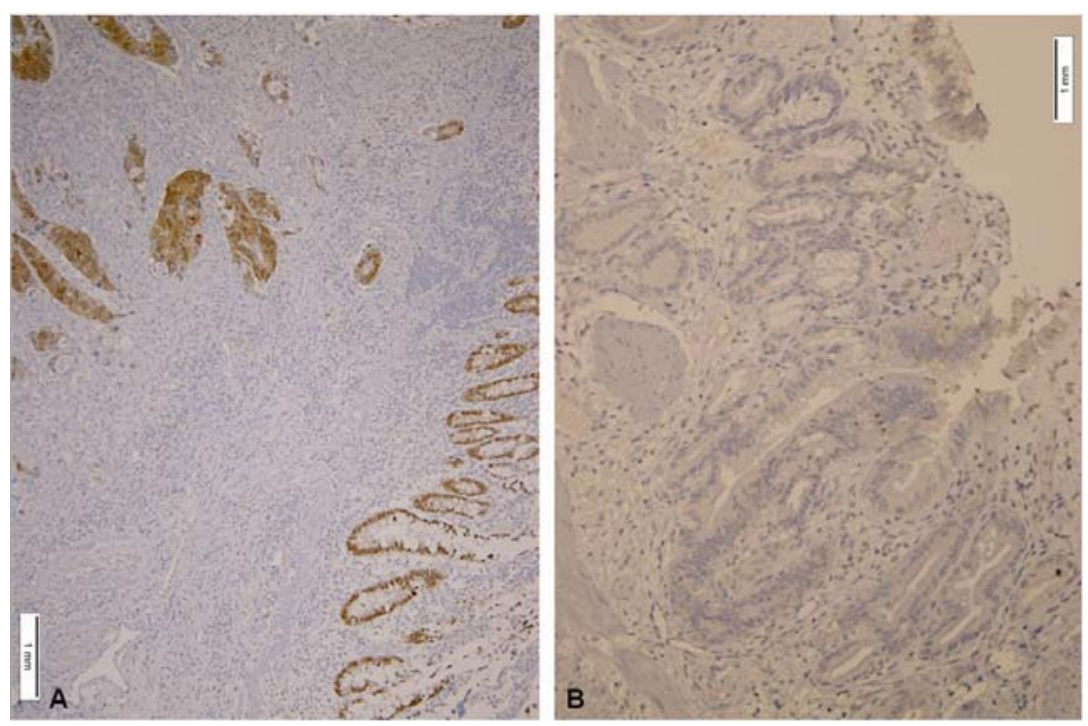

\section{Discussion}

Multiple primary malignant tumors in the same patient is relatively rare with a $0.7 \%-11.7 \%$ overall occurrence ${ }^{[14]}$. However, the incidence is increasing worldwide with increase in the number of cancer survivors due to advances in diagnostic techniques and treatment modalities ${ }^{[15,16]}$. According to Waren and Gates ${ }^{[1]}$, the diagnostic criteria of multiple primary cancers are: first, each tumor should be histopathologically malignant; second, each tumor should be histologically different; and third, the possibility of metastasis of each tumor should be ruled out. These criteria fully apply to the case we are reporting in which the two synchronous cancers showed immunohistochemical differences as outlined above.

The carcinogenic process involved in the development of multiple primary cancers has not been clarified and hereditary and environmental factors, and radiological and anticancer treatments have been implicated ${ }^{[16]}$. Methylenetetrahydrofolate reductase (MTHFR) is an enzyme that takes part in acid metabolism, catalizes the conversion of 5, 10methylenetetrahydrofolate to 5-methyltetrahydrofolate, a co-substrate for homocysteine remethylation to methionine, and plays a major role in DNA methylation ${ }^{[17,18]}$. Many studies found that genetic variation of MTHFR might influence the susceptibility to colon cancer, and may also affect extracolonic cancers such as breast, ovarian and other cancers ${ }^{[19,20]}$. 
Age seems to be an important factor as most of the cases reported in the literature have occurred in elderly patients. In a study of 134 cases of colorectal cancer with synchronous and metasynchronous cancers, Samadder et al. found that the risk for synchronous colorectal cancer was higher in age $>65$ years ${ }^{[21]}$. However, our patient was much younger than 65 (only 30 years old).

Reported MPMTs include variable combinations of colorectal, gastric, breast, gynecologic, prostatic, renal, bladder, thyroid, intracranial, and head and neck cancers ${ }^{[15]}$ with the colon being the organ that is most frequently involved ${ }^{[3]}$. Thus patients with colon cancers may probably be at increased risk of developing other primary malignancies. Consequently, thorough preoperative screening and follow up for other cancers is recommended for patients presenting with colorectal carcinoma.

Synchronous adenocarcinomas of the colon and the gallbladder are extremely rare. To the best of our knowledge only seven cases have been previously reported. The following table shows the main clinicopathological features of five of those cases as compared to ours.

Table. Clinicopathological features of five previously reported synchronous colon and gall bladder carcinomas, compared to present case

\begin{tabular}{|c|c|c|c|c|c|c|c|c|c|}
\hline \multirow[b]{2}{*}{ Author } & \multirow[b]{2}{*}{ Year } & \multirow{2}{*}{$\begin{array}{l}\text { Age/ } \\
\text { Sex }\end{array}$} & \multicolumn{3}{|c|}{ Colon cancer } & \multicolumn{3}{|c|}{ GB Cancer } & \multirow{2}{*}{$\begin{array}{l}\text { Other synchronous } \\
\text { cancers }\end{array}$} \\
\hline & & & Location & Histology & $\begin{array}{l}\text { Stage } \\
\text { (TNM) }\end{array}$ & Location & Histology & $\begin{array}{l}\text { Stage } \\
\text { (TNM) }\end{array}$ & \\
\hline $\begin{array}{l}\text { Konodo } \\
\text { et al. }{ }^{[6]}\end{array}$ & 1985 & $60 \mathrm{y} / \mathrm{M}$ & SC & $\begin{array}{l}\text { Well } \\
\text { diffrenetiat } \\
\text { ed adenoCa }\end{array}$ & - & - & $\begin{array}{l}\text { In situ } \\
\text { adenocarCa }\end{array}$ & pTis & $\begin{array}{l}\text { Early, poorly } \\
\text { differentiated } \\
\text { squamous carcinoma } \\
\text { of the esophagous }\end{array}$ \\
\hline $\begin{array}{l}\text { Schmid } \\
\text { et al. }{ }^{[7]}\end{array}$ & 1988 & $79 y / F$ & TC & $\begin{array}{l}\text { Mucinous } \\
\text { carcinoma }\end{array}$ & pT3 & $\begin{array}{l}\text { No } \\
\text { macroscop } \\
\text { ic evidence }\end{array}$ & $\begin{array}{l}\text { Well } \\
\text { differentiat } \\
\text { ed adenoCa }\end{array}$ & pT2 & $\begin{array}{l}\text { Early, non invasive } \\
\text { adenoCa of the apex } \\
\text { of the appendix }\end{array}$ \\
\hline $\begin{array}{l}\text { Tamura } \\
\text { et al. }{ }^{[9]}\end{array}$ & 2003 & $70 \mathrm{y} / \mathrm{M}$ & SC & $\begin{array}{l}\text { Well } \\
\text { diffrenetiat } \\
\text { ed adenoCa }\end{array}$ & I & Fundus & $\begin{array}{l}\text { Papillary } \\
\text { adenoCa }\end{array}$ & I & $\begin{array}{l}\text { Well differentiated } \\
\text { adenoCa of the } \\
\text { stomach, stage II }\end{array}$ \\
\hline $\begin{array}{l}\text { Sakellar } \\
\text { idis et } \\
\text { al. }{ }^{[10]}\end{array}$ & 2005 & $72 y / F$ & $\mathrm{R}$ & $\begin{array}{l}\text { Moderately } \\
\text { differentiat } \\
\text { ed adenoCa }\end{array}$ & II & $\begin{array}{l}\text { Anterior } \\
\text { wall }\end{array}$ & $\begin{array}{l}\text { Well to } \\
\text { moderately } \\
\text { differentiat } \\
\text { ed adenoCa. }\end{array}$ & II & Absent \\
\hline $\begin{array}{l}\text { Gupta } \\
\text { et al. }{ }^{[11]}\end{array}$ & 2013 & $40 y / F$ & $\mathrm{R}$ & $\begin{array}{l}\text { Moderately } \\
\text { differentiat } \\
\text { ed adenoCa }\end{array}$ & IIA & $\begin{array}{l}\text { Antero } \\
\text { medial } \\
\text { wall }\end{array}$ & $\begin{array}{l}\text { Moderately } \\
\text { differentiat } \\
\text { ed adenoCa }\end{array}$ & II & Absent \\
\hline $\begin{array}{l}\text { Present } \\
\text { case }\end{array}$ & 2014 & $30 y / F$ & SC & $\begin{array}{l}\text { Moderately } \\
\text { differentiat } \\
\text { ed adenoCa }\end{array}$ & IIIC & $\begin{array}{l}\text { No } \\
\text { macroscop } \\
\text { ic evidence }\end{array}$ & $\begin{array}{l}\text { In situ } \\
\text { adenoCa }\end{array}$ & pTis & Absent \\
\hline
\end{tabular}

Note. SC = Sigmoid colon; $\mathrm{TC}=$ Transverse colon; $\mathrm{R}=$ Rectum; adenoCa = Adenocarcinoma; GB = Gall bladder

The link between the colonic and the gall bladder carcinomas may reside in the presence of gall stones rather than a hereditary predisposition to cancer development as may be suggested by the negative family history for colorectal and gallbladder cancers. Reports of high fecal excretion of bile acids and bile derivatives by patients with colorectal cancer and those with cholecystectomy have intensified research into the relation between gall stones and colorectal cancer ${ }^{[2]}$. Several studies of gall stone patients have been reported ${ }^{[23-32]}$; most showed a positive association with cancer of the colon, with relative risks of 1.2-2.4. In the studies that showed an effect and provided data on risk by anatomical sub-site, the risk was generally greater for cancer of the proximal colon than for other parts of the colon and rectum ${ }^{[28-32]}$. 
Gall bladder cancer is a notoriously rare though lethal malignancy with marked geographic variation. Risk factors for developing gall bladder cancer include ethnicity, female sex, old age, genetic susceptibility, lifestyle, and chronic inflammation which is often a product of gall stones ${ }^{[33]}$.

\section{Conclusion}

The incidence of multiple primary malignant tumors in the same individual is increasing worldwide. Because the colon is the organ that is most frequently involved in such a setting, thorough preoperative screening and follow up for other cancers, including gallbladder cancer, is recommended for patients presenting with colorectal carcinoma.

\section{Competing interests}

The authors declare that they have no competing interests.

\section{References}

[1] Warren S, Gates O. Multiple primary malignant tumors. A survey of the literature and a statistical study. Am J Cancer. 1932; 16: 1358-1414.

[2] Kilciksiz S, Gokce T, Baloglu A, Calli A, Kaynak C, Kilic B, et al. Characteristics of synchronous- and metachronous-type multiple primary neoplasms: A study of hospital-based cancer registry in Turkey. Clinical Genitourinary Cancer. 2007; 5(7): 438-45. PMid: 18272026. http://dx.doi.org/10.3816/CGC.2007.n.032

[3] Lee TK, Barringer M, Myers RT, Sterchi JM. Multiple primary carcinomas of the colon and associated extracolonic primary malignant tumors. Ann Surg. 1982; 195(4): 501-7. PMid: 7065754. http://dx.doi.org/10.1097/00000658-198204000-00020

[4] Shah IA, Alfsen GC. Multiple primary malignant tumors involving the large bowel. Diseases of the Colon \& Rectum. 1984; 27(12): 798-802. http://dx.doi.org/10.1007/BF02553943

[5] Tomin R. Simultaneous cancer of the rectum and gallbladder. Srp Arh Celok Lek. 1965; 93(3): 323-7. PMid: 5861499.

[6] Kondo T, Ishii Y, Kobayashi S, Moriwaki M, Sakurai H, Okamura H, et al. A case of triple simultaneous cancer of the esophagus, gallbladder and colon. Gan No Rinsho. 1985; 31(14): 1849-53. PMid: 4087393.

[7] Schmid KW, Glaser K, Wykypiel H, Feichtinger H. Synchronous adenocarcinoma of the transverse colon, the gallbladder and the vermiform appendix. Klin Wochenschr. 1988; 66(21): 1093-6. PMid: 3236758. http://dx.doi.org/10.1007/BF01711925

[8] Yazawa K, Tsuge Y, Takahashi C, Ichijo M, Matsuzaki O. A case of synchronous triple early cancer occurring in the stomach, colon and gallbladder.

[9] Tamura M, Shinagawa M, Funaki Y. Synchronous triple early cancers occurring in the stomach, colon and gallbladder. Asian J Surg. 2003; 26(1): 46-9. http://dx.doi.org/10.1016/S1015-9584(09)60216-5

[10] Sakellaridis T, Mathioulakis S, Antiochos C. Synchronous early primary adenocarcinoma of both rectum and gallbladder. Report of a case. International Seminars in Surgical Oncology. 2005; 2: 19. http://dx.doi.org/10.1186/1477-7800-2-19

[11] Gupta V, Goel MM, Kumari M, Noushif M, Ghandi JS, Chandra A. Non-familial synchronous double primary malignancies of the gallbladder and rectum. J Gastrointest cancer. 2013; http://dx.doi.org/10.1007/s12029-013-9551-1

[12] Juhasz ES, Wolf BG, Meagher AP, Kluiber RM, Weaver AL, Van Heerden JA. Incidental cholecystectomy during colorectal surgery. Ann Surg. 1994; 219(5): 467-74. PMid: 8185397. http://dx.doi.org/10.1097/00000658-199405000-00004

[13] Beart RW. Risk of additional intra-abdominal procedures at the time of colectomy. Diseases of the Colon \& Rectum. 1982; 25(3): 185-6. http://dx.doi.org/10.1007/BF02553097

[14] Demandante CG, Troyer DA, Miles TP. Multiple primary malignant neoplasms: case report and acomprehansive review of the literature. Am J Clin Oncol. 2003; 26(1): 79-83. PMid: 12576929. http://dx.doi.org/10.1097/00000421-200302000-00015

[15] Babakan NA, Askoy S, Cetin B, Ozdemir NY, Benekli M, Uyeturk U, et al. Multiple primary malignant neoplasms: Multi-center results from Turkey. Journal of BUON. 2012; 17: 770-75.

[16] Lee JW, Kim JW, Kim NK. Clinical characteristics of colorectal cancer patients with a second primary cancer. Ann Colpoproctol. 2014; 30(1): 18-22. PMid: 24639966. http://dx.doi.org/10.3393/ac.2014.30.1.18

[17] Choi SW, Mason JB. Folate and carcinogenesis: an integrated scheme. J Nutr. 2000; 130: 129-32. PMid: 10720158.

[18] Kuismanen SA, Holmberg MT, Salovaara R, Schweizer P, Aaltonen LA, De La Chapelle A, et al. Epigenetic phenotypes distinguish microsatellite-stable and -unstable colorectal cancers. Proc Natl Acad Sci USA. 1999; 96: 12661-6. PMid: 10535979. http://dx.doi.org/10.1073/pnas.96.22.12661

Published by Sciedu Press 
[19] Chen J, Giovannucci E, Kelsey K, Rimm EB, Stampfer MJ, Colditz GA, et al. A methylenetetrahydrofolate reductase polymorphism and the risk of colorectal cancer. Cancer Res. 1996; 56: 4862-4. PMid: 8895734.

[20] Gershoni-Baruch R, Dagan E, Israeli D, Kasinetz L, Kadouri E, Friedman E. Association of the C677T polymorphism in the MTHFR gene with breast and/or ovarian cancer risk in Jewish women. Eur J Cancer. 2000; 36: 2313-6. http://dx.doi.org/10.1016/S0959-8049(00)00306-3

[21] Samadder NJ, Curtin K, Wong J, Tuohy TMF, Mineau GP, Smith KR, et al. Epidemiology and familial risk of synchronous and metachronous colorectal cancer: A population-based Study in Utah. Clin Gastroenterol Hepatol. 2014 Apr 24. pii: S1542-3565(14)00605-3. http://dx.doi.org/10.1016/j.cgh.2014.04.017

[22] Johansen C, Chow W-H, Jorgensen T, Mellemkjaer L, Engholm G, Olsen JH. Risk of colorectal cancer and other cancers in patients with gall stones. Gut. 1996; 39: 439-443. PMid: 8949651. http://dx.doi.org/10.1136/gut.39.3.439

[23] Doouss TW, Castleden WM. Gallstones and carcinoma of the large bowel. NZ Med J. 1973; 77: 162-5. PMid: 4512660.

[24] Turunen MJ, Kivilaakso EO. Increased risk of colorectal cancer after cholecystectomy. Ann Surg. 1982; 194: 639-41. http://dx.doi.org/10.1097/00000658-198111000-00014

[25] Lowenfels AB, Domellöf L, Lindström CG, Bergman F, Monk MA, Sternby NH. Cholelithiasis, cholecystectomy and cancer: a case-control study in Sweden. Gastroenterology. 1982; 83: 672-6. PMid: 7095370.

[26] Von Schmauss, Ehrhardt U. Cholelitihasis - cholezystektomie und kolonkarzinom. Zentralbl Chir. 1983; 108: $449-56$.

[27] Allende H, Ona FV, Davis HT. Gallbladder disease: risk factor for colorectal carcinoma? Jf Clin Gastroenterol. 1984 ; 6: 51-5. PMid: 6699393.

[28] Machnik G, Füller C, Füller J, Kunath H. Exploratory studies of the common incidence of cholelithiasis, status following cholecystectomy and colonic cancer. Dtsch Z Verdau-Stoffwechs. 1986; 46: 22-9. PMid: 3720630.

[29] Gafa M, Sarli L, Sansebastiano G. Prevention of colorectal cancer. Dis Colon Rectum. 1987; 30: 692-6. PMid: 3622176. http://dx.doi.org/10.1007/BF02561690

[30] Maringhini A, Moreau JA, Melton LJ, Hench VS, Zinsmeister AR, DiMagno EP. Gallstones, gallbladder cancer, and other gastrointestinal malignancies. Ann Intern Med. 1987; 107: 30-5. PMid: 3592446. http://dx.doi.org/10.7326/0003-4819-107-1-30

[31] Breuer NF, Katschinski B, Mörtl E, Leder LD, Goebell H. Large bowel cancer risk in cholelithiasis and after cholecystectomy. Digestion. 1988; 40: 219-26. PMid: 3234628. http://dx.doi.org/10.1159/000199658

[32] Jorgensen T, Rafaelsen S. Gallstones and colorectal cancer- there is a relationship, but it is hardly due to cholecystectomy. Dis Colon Rectum. 1992; 35: 24-8. http://dx.doi.org/10.1007/BF02053334

[33] Stinton LM, Shafer EA. Epidemiology of Gallbladder Disease: Cholelithiasis and Cancer. Gut Liver. 2012; 6(2): $172-187$. 